\title{
Information Technology and Journalism Practice in Nigeria: A Survey of Journalists in Portharcourt Metropolis
}

\author{
Godwin Okon ${ }^{1} \&$ Timothy Eleba ${ }^{1}$ \\ ${ }^{1}$ Department of Mass Communication, Rivers State University of Science and Technology, Portharcourt, Nigeria \\ Correspondence: Godwin Okon, Department of Mass Communication, Rivers State University of Science and \\ Technology, PMB 5080, Portharcourt, Nigeria. E-mail: okon.godwin@ust.edu.ng
}

Received: August 12, 2013

Accepted: September 22, 2013 Online Published: October 11, 2013

doi:10.5539/res.v5n5p111

URL: http://dx.doi.org/10.5539/res.v5n5p111

\begin{abstract}
The thrust of this study was predicated on the need to ascertain the extent to which Nigerian journalists, especially those in Portharcourt metropolis, have integrated the use of information technology (IT) in their professional repertoire. The objectives among others included the need to streamline the challenges, if any, journalists face in the adoption of new information technologies (ITs). The study by its nature necessitated survey. To this end, one hundred and twenty (120) journalists were sampled with a view to dovetailing their responses within a scholarly spectrum. Findings revealed that $67 \%$ of the respondents use IT facilities in their day to day operations. Data further revealed that IT facilities in the various media houses studied were obsolete and inadequate. The challenges faced by journalists in the deployment of IT facilities were identified as lack of access to emerging information technologies as well as the absence of a framework for the training and retraining of journalists on information technology hardware and software configurations. It was therefore recommended that media proprietors should provide as part of the work environment, IT facilities to enable journalists discharge their duties in line with international best practices.
\end{abstract}

Keywords: adoption, information, technology, journalism, proficiency

\section{Introduction}

The business of journalism in present day Nigeria has taken cognizance of new Information Technologies (ITs) just like other developing countries of the world. The term is commonly used with computers and computer networks, but it also encompasses other information distribution technologies such as television and telephones. Before now, newspapers and magazines were the only forms of print media until 1430-1450, when in Europe letters, books, posters, and other printed materials were added to the print media. These media of communication are essential tools for creating, expressing and moulding public opinion on topical issues.

The implication however is that much time and effort was expended in a bid to communicate with friends, families and business partners. However, Nsereka (2012) posits that journalism has moved from what can merely be seen in the content of newspapers to "cover the chronicling and interpretation of current events through many media which include newspapers, radio, television, magazines, films, etc." (p. 3). The internet and its accompanying social networks are, of course, not outside this spectrum in contemporary times.

Asadu (2009) notes that the "transformation of the mass media landscape by information and communication technology (ICT) has opened a vista of opportunities and challenges for journalists" (p. 82). In this new and technologically driven world, the profession of journalism has continued to prove interesting and challenging and modern-day journalists succeed in a lot more ways. They work occurrences, facts, ideas and opinions into intelligible and comprehensible messages received by thousands of millions of people, all over the world. They are gate-keepers who make important decisions before taking their piece to the editor and the receiving audience.

Udeze (2012) has further noted that "in most developed and developing cultures, the internet is used to mobilize or encourage people to embrace a particular programme or idea" (p. 54). Indeed, journalism practice in the modern world has experienced a paradigm shift necessitated by changes and innovations in information technologies. We see that journalism is experiencing a renaissance and communication scholars agree to the fact that the internet is a rapidly evolving medium disparate from the traditional media, and is redefining the conventional process. For instance, the phrases: "open source journalism," "citizen journalism" and such other terms which refer to unpaid 
citizens, pseudo journalists who submit quasi-information to websites (such as Facebook, YouTube, Tweeter etc.). Web account of an African roasted for a barbeque in China; June, 2009 facebook upload of the demonstration over the execution of an African in China are some typical examples.

This kind of "journalism by the people" has been a controversial subject: professional journalists are yet in a state of confusion, especially because of the high level of unethical indulgence by the so called citizen journalists. According to Okon (2001), since these technologies and media forms are alien to the Nigerian society, in particular, media houses and journalists should try as much as possible to acquire the required skills while adopting and adapting to state-of-the-art equipment in gathering, packaging and disseminating news and other relevant information to the public.

The internet has made journalism practice easier for journalists via the exchange of messages with professionals and experts in various disciplines. This has introduced new market and new form of journalism in which journalists specialise as online journalists, content managers and editors for some websites/media organisations. This has made it imperative for them to train to acquire blogging skills, creating hypertext, adding contents to web pages, taking and uploading digital pictures. This study therefore sets out to ascertain the extent to which Nigerian journalists have integrated the use of information technology into their professional repertoire.

\section{Statement of the Problem}

The presence of information and communication technology (ICT) in the journalism profession of Nigeria has presented challenges and opportunities as well as development. However, studies have revealed that most Nigerian journalists lack the requisite knowledge/finesse to operate in the new media environment that is transforming the nature and mode of operation of the media in bringing about development (by providing information or programmes that will expedite rapid development). It is however, unfortunate that the requisite state-of-the-art media gadgets or equipment needed for the media to function effectively in the above area are scarcely available to the journalist.

The new info-tech has helped editors/gate keepers in alleviating work-load and the reporter in preparing copies (reduction of errors and the pressure of meeting up with deadline etc.). The importance of ITs cannot be over-emphasized thus making it imperative for Nigerian media organisations to adopt and adapt to the new media environment.

It is however, germane, though unfortunate, to add here that despite the new technologies in the sphere of journalism, it has increased the craze of unethical practices (where anyone can just write and disseminate information on the web without editing) thereby threatening the integrity and dignity of the journalism profession.

However, the personal computer, the digital camera, the mobile phone and internet have challenged traditional journalism on almost every frontier. The global update of digital media has spawned user-generated contents and citizen journalism; the video journalist and the blogger, social networking sites and the massively, multiplayer online game. How Nigerian journalists, especially those in Portharcourt metropolis, have optimized the use of information technology in their professional scheme is therefore the concern of this study.

\section{Study Objectives}

The concern of this study is to particularly focus on journalists in Port Harcourt in terms of new media applications. Therefore the study serves to;

(1) Find out if the journalists in Port Harcourt metropolis make use of new technologies in carrying out their duties

(2) Identify the challenges journalists face in the adoption of new information technologies (ITs).

\section{Research Questions}

(1) To what extent do journalists in Port Harcourt metropolis make use of the new ITs in discharging their duties?

(2) What challenges do journalists in portharcourt metropolis face in adopting new information technologies?

\section{Review of Literature}

The rapidity and sophistication with which information and/or news is disseminated across the globe in the modern world via information technologies - especially the Internet/www cannot be over-emphasized. Fidler (2005) informs that the birth of new media does not precipitate the death of old media, rather than that, it evolves and adapt to changing media environment in a gradual process. Hence, it brings about improved and easier ways of handling communication tasks. 
Rodman (2012) capitulates that the history of development is inextricably linked to the history of the mass media. Journalism has continued to undergo much changes occasioned by innovations in information and communication technology in copy writing, reporting, page making, editing and filming as well as the whole production process. The journalism industry has experienced a land mark revolution brought upon it by advances in info-tech. in accordance with the foregoing, modern-day journalists must consider it an obligation to deal with issues pertaining to them. Lending credence to the above,

Uwakwe (2012) notes that:

In the mid 1990s, the www brought wide changes to the mass media. By this time, newspapers, magazines, TV and radio began to use the web in providing electronic access to information. It became possible to have access to both current and past information. Today, with a wide range of newspapers, any person can have access to previously published works. Some of these works have hyperlinks to many other texts as well as videos. About 20 years ago, reporters in Nigeria knew nothing about electronic data basis. Today, an array of electronic data basis and archives in addition to ever-growing digital options are playing full time on the field of digital convergence. Today, the newsroom is replete with technological devices not available to practitioners a few decades age (p. 3).

At present, the availability of technological devices to some journalists in Nigeria (especially those who have computer related skill) has made it easy for them to type their stories on computers and/or word processors and this technology helps them to check and correct grammatical and spelling errors immediately. When journalists are done with typing, their stories are stored in a computer. The editor may be able to view the story in another remote screen if the systems are in a network, a kind of intranet. When the editor is done with the work, the story is finally transmitted to another computer, which sets the words in type. Journalism practice has indeed entered electronic age.

Okon (2001) seems to support this when he informed that "information is perceived as a means of production as well as the product itself." Similarly, McQuail (1993) cited in Okon (2001) posits that "the labour force will consist of information workers, referring to journalists and information will also be dominant economically and socially" (p. 273).

Chan-de Liu (2006) argues that Participation which necessitates reasoning and moreover trust, will help reduce the social distance between communicators and receivers, between teachers and learners, between leaders and followers as well as facilitate a more equitable exchange of ideas. This draws attention to the fact that ITs have made exchange of ideas between communicators and receivers easier. Hence, making the communication process people centred. One of the salient features of ITs in news reporting is that news is timely and immediate since the emergence of computer technology. It is evident that ICTs have had a tremendous impact on how fast content reaches the target audience. Unlike in the past when the mass media audiences largely relied on newspapers and broadcast media (radio and television) to present information or news the following day through special editions, and at the slotted news hour. ICTs have made it even easier to publish information in real time, updating breaking news and events as they happen (Muga, 2006).

Samadar (1995), points out that ICT facilitates the creation, storage, management and dissemination of information by electronic means. This draws attention to the fact that, with ITC in place, news dissemination has been made easier with unbeatable fidelity. Still in line with this, Carlson (2005) argues that, "The development of innovative information technologies and the ongoing processes of deregulation and concentration of ownership have spurred the space of globalisation, especially communication satellites and digitalization with an enormous impact" (p. 204).

ICT has had several effects on journalism, with some of them seen as advantages while others as disadvantages. As Okunna (1999) notes, the computer and the modem, with many other ICT hardware and software innovations and services, have placed us at a high point of a very significant stage of development in the history of human communication, often called, "the information society, or "information superhighway," and have transformed the way many men and women work in the media and entertainment industries. In stating media convergence and the relationship of media houses and their audience John Pavlik and Shawn McIntosh (2005) note that:

Audiences in the age of convergence can communicate via e-mail, online forums and other interactive media more easily and quickly with those who create and publish mass communication content... They can create mass communication content themselves and reach far larger audiences for much lower costs...compared to the traditional media (p. 69). 
It can be inferred from the foregoing that the advent of the Internet/www (as a result of media convergence) has made the journalist a receiver/audience rather than the "sole sender" as he too monitors and watches out for information, on the web, that are important to him. Computerization in digital media allows for mass communication organisations to keep detailed and automatically updated records on their audiences as they track their paths within their web sites through intelligent software agents and programmes known as cookies. This helps media houses to get invaluable information to better understand their audiences' media behaviours, preferences and habits, Pavlik and McIntosh (2005).

Information Communication Technology (ICT) has led to the generation of more and well researched news. With mobile phones, the journalist/reporter can call news sources at any time and get relevant information. When it comes to the Internet, news and programme backgrounders are always available. Think of any topic you are working on, from health, education, lifestyle, to environment etc., you cannot fail to get information to help you enrich your story especially with those hard-to-get facts. The Internet has really transforms the newsroom to greater heights. It is important to note that this comes as a result of globalization and it is also a cause of globalization in one way. Ulla Carlson (2005) argues that, "The development of innovative information technologies and the ongoing processes of deregulation and concentration of ownership, have spurred the pace of globalization especially communications satellites and digitalization- not least the Internet- have had an enormous impact" (p. 204).

Information Communication Technology (ICT) has created a network that leaves reporters and editors in close contacts at any one time. The editor can at any time call the reporter who is situated in any place, as long as there is telephone network there, and get a story from him. Likewise, reporters file stories at any given time via the Internet. A Zambian web development specialist Kunda Chinyanta Mwila, while speaking in an interview RAP 21, about the future of ICT and Africa newspapers, stated that, "Mobile and satellite telephones and general improvement of landlines, have made it possible for newspapers to get stories from a reporter stationed anywhere in the world." No matter where a reporter is stationed, he/she is always connected and close to the newsroom.

It is worth noting that ICT has made the communication process participatory; listeners are able to pick their phones and call the radio or TV stationers immediately and inform the presenter about occurrences unknown to them. Reporters later investigate on such issues. Servaes and Malikhao (2000) argue that, "Participatory, which necessitates reasoning and moreover trust will help reduce the social distance between communicators and receivers... as well as facilitate a more equitable exchange of ideals" (p. 591).

In the developing worlds, ICT is revolutionizing the journalism profession. Journalists are able to receive hands on training just online. Journalists also listen/read stories from other media houses and compare their styles to see what makes them succeed in the business.

On the other hand, ICT has caused unemployment in the journalism profession, as Wilson (2005) says that those who cannot operate media devices have been left behind. One is compelled to go for further training or lose a job. Take an example where DJs have to use computers while broadcasting live; if he does not know how to operate it, automatically he loses his job.

According to a research by Obijiofor (2003) titled "New Technologies and Journalism Practice in Nigeria and Ghana", questionnaires were designed and administered personally by the researcher to a total of 100 Nigerian and Ghanaian journalists (working in three newspaper houses in Nigeria; The Guardian, This Day and Daily Champion and two newspapers, The Graphic and Chronicle in Ghana) over a period of two weeks. The questionnaire was aimed at uncovering Nigerian and Ghanaian journalists' attitudes and perceptions of the new technologies in their professional practice. The results of this study revealed that there is a considerable agreement among the journalists sampled in Nigeria and Ghana that new technologies have improved rather than harmed the quality of newspapers in their countries. The researcher informs that nine out of ten journalists (96.2\%) say that new technologies have improved the quality of their newspapers; that no journalist says that new technologies have harmed the quality of their newspapers. However, he informs further that one respondent ( 2 percent) was unsure whether new technologies have improved or harmed the quality of newspapers production. There is need for greater empiricsm especially for journalists in Portharcourt.

\section{Methodology}

The nature of this study necessitated the survey research method. The survey method according to Ohaja (2009) is "the most common method of gathering primary research data in which the researcher gains information on attitudes, opinions or motivations by questioning respondents" (p. 9). In the same vein, Okwandu (2007) further posits that "considerations of questionnaires for use in data collection requires an awareness of the assumptions 
inherent in the study propositions" (p. 132). To this end, questionnaire was administered to ascertain the attitudes or opinions of journalists in Port Harcourt pertaining to the effect of new ITs on the journalism profession.

According to official records from the secretariat of the Nigeria Union of Journalists in Portharcourt (NUJ record, 2013), there are 350 journalists in Port Harcourt. However, in order to get a fair representation of journalists in Port Harcourt, some media houses (Rhythm [93.7FM], Tide newspaper, and RSTV channel 22) were purposively selected. However, it is pertinent to add that the choice of the aforementioned media houses is informed by the fact that data from these media houses can be used to represent other media houses. Besides, these media houses were purposively selected based on the fact that they maintain a dominant posture in the print and electronic media landscape of Rivers state. It is therefore the considered opinion of this study that the journalists in these media houses inadvertently present a representative sample.

Forty (40) copies of the questionnaire were administered to each of the purposively selected media houses in Port Harcourt metropolis consisting of Rhythm [93.7FM], Tide, and RSTV in Port Harcourt Metropolis. Hence, a total number of 120 copies of the questionnaire were administered.

Analysis was done using simple percentage and frequency tables. Freud and Williams (1979) opine that the simple percentage as a tool for analysis is considered adequate

\section{Data Presentation}

Table 1. Sex distribution of the respondents

\begin{tabular}{lcc}
\hline Sex & Number of respondents & Percentage of respondents \\
\hline Male & 75 & $62.5 \%$ \\
Female & 45 & $37.5 \%$ \\
Total & 120 & 100 \\
\hline
\end{tabular}

The table above shows the sex distribution of the respondents. Out of the total of 120 respondents, 75 respondents accounting for $62.5 \%$ were male, while 45 respondents which accounts for $37.5 \%$ were female. With all indication, the male respondents were more than the female respondents.

Table 2. The educational level of the respondents

\begin{tabular}{lcc}
\hline Educational Level & Number of respondents & Percentage of the respondents \\
\hline SSCE & 30 & $25 \%$ \\
Diploma/Bs.c & 70 & $58.3 \%$ \\
Master & 20 & $16.6 \%$ \\
Total & 120 & 100 \\
\hline
\end{tabular}

The table above shows the education/qualification of the respondents. Out of the 120 respondents, 30 which represents $25 \%$ has senior secondary school certificate, while 70 which represents $58.3 \%$ posses Diploma/Bs.c, whereas 20 which represents $16.6 \%$ possesses Masters. Obviously, the respondents who possess Diploma/ Bs.C ranked highest.

Table 3. Respondents' professional status

\begin{tabular}{lcc}
\hline Position & Number of respondents & Percentage of the respondents \\
\hline Reporter & 60 & $50 \%$ \\
Editor & 20 & 16.6 \\
Manager & 40 & $33.3 \%$ \\
Total & 120 & 100 \\
\hline
\end{tabular}

From the table above, it is shown that out of the 120 respondents, 60 which represent $50 \%$ were reporters while, 20 which represent $16.6 \%$ were editor whereas, 40 which represent $33.3 \%$ hold the position of managers. However, the table shows that the majority of the respondents were Reporters. 
Table 4. Challenges faced by journalists in adopting ITs

\begin{tabular}{lcc}
\hline Opinion & Number of respondents & Percentage of the respondents \\
\hline $\begin{array}{l}\text { Lack of access to new technologies } \\
\text { Lack of exposure and training }\end{array}$ & 40 & $33.3 \%$ \\
programs to acquire skills & 70 & 58.3 \\
$\begin{array}{l}\text { None of the above } \\
\text { Total }\end{array}$ & 10 & $8.3 \%$ \\
\hline
\end{tabular}

From the table above, out of the 120 respondents, 40 which represent $33.3 \%$ were of the opinion that in adapting to the new information technologies, they encounter the problem of lack of access to the new information technologies ranging from inadequacies or computers that are not in vogue and limited access to the internet facilities in the media houses. While 70 which represent $58.3 \%$ were of the opinion that in the process of adopting the new information technologies they encounter the problem of lack of exposure and training/re-training which resulted to lack of knowledge and this affected their job performance negatively. Whereas, 10 which represents $8.3 \%$ say that they did not encounter the aforementioned problems, which points to the fact that they are doing well as journalists/reporters considering that they have their own computers (or laptops, iphones) with internet facility.

Table 5. Performance rating with the use of ITs

\begin{tabular}{lcc}
\hline Opinion & Number of respondents & Percentage of the respondents \\
\hline It makes work easier and & 105 & $87.5 \%$ \\
qualitative & & \\
Some-how & 5 & $4.1 \%$ \\
More complicating & 10 & $8.3 \%$ \\
Total & 120 & 100 \\
\hline
\end{tabular}

From the above table, out of the 120 respondents, 103 which represent $87.5 \%$ were of the opinion that the new information technologies make work easier and qualitative in terms of production speed, use of coloured photographs, improvement in physical appearance of the newspaper to simplicity of effecting corrections and checking of spelling. While 5 which represents $4.1 \%$ were of the view that the ICTs make little difference in journalism as a profession. Whereas 10 which represent $8.3 \%$ of the respondents were of the opinion that ICTs are more complicating in nature, as in the more technology grows, the more stuff you don't know about them and the more you go for re-training.

Table 6. Use of ITs in daily operations

\begin{tabular}{lcc}
\hline Opinion & Number of respondents & Percentage of the respondents \\
\hline Yes & 80 & $67 \%$ \\
No & 40 & $33 \%$ \\
\hline
\end{tabular}

The table above shows that 80 respondents which represent $67 \%$ were of the opinion that they do make use of the new information technologies in discharging their duties as journalists- though most of them only do so from a public internet centre. However, $33 \%$ was of a different opinion.

Table 7. Adequacy of IT facilities in media houses

\begin{tabular}{lcc}
\hline Opinion & Number of respondents & Percentage of the respondents \\
\hline Adequate & 26 & $21.6 \%$ \\
Fairly adequate & 30 & $25 \%$ \\
Not adequate & 64 & $53.3 \%$ \\
Total & 120 & 100 \\
\hline
\end{tabular}

The table above shows that out of the 120 respondents, 26 which represent $21.6 \%$ opined that they are satisfied with the level of equipment (ITs) in their media houses, though they have not all upgraded to digital technologies 
because they are considerably expensive to adopt. While, 30 which represent $25 \%$ were not all that satisfied, that is some-how satisfied with the level of ITs in their media houses whereas, 64 which represent $53.3 \%$ were of the opinion that they are not satisfied with the level of available ICTs devices in their media houses. For the first two categories, their positions are informed by the fact that the media gadgets in their media organisations are obsolete, some have low definition and support few applications and are not readily always available for use, respectively. However, the table indicates that a greater number of the respondents was not satisfied with the level of available media gadgets (ITs) in the media houses.

The summation however is that Nigerian journalists are favourably disposed to inculcating into their day to day practice, the hardware and software configurations of the emerging information technology. The challenge however is the paucity of IT applications in the various media houses. It was further found that the few available, in most media houses, were obsolete. The adverse consequences border on their inability to adapt to emerging modes.

\section{Recommendations}

Since journalists have expressed enthusiasm in embracing the opportunities that typify the acquisition and use of Information Technology for enhanced efficiency, it has therefore been recommended that;

1) Media proprietors should provide, as part of the work environment, IT software and hardware configurations so as to enable journalists align their day to day operations with international best practices.

2) Journalists should always avail themselves of opportunities that provide for training and retraining so as to enhance their proficiency in the deployment of IT components.

3) The government should provide an enabling environment, in terms of waiver clauses on IT components, to allow for ease in acquisition of IT facilities across socio-economic strata.

\section{References}

Asadu, C. A. (2009). Anatomy of communication for development. Rivers State, Nigeria: University of Port Harcourt Press.

Campbell, D. (2001). Can the digital divide be contained? International Labour Review, 140(2), 119-141. http://dx.doi.org/10.1111/j.1564-913X.2001.tb00217.x

Carlson, U. (2005). From NWICO to Global governance of the information society. In O. Hemer, \& T. Tufte (Eds.), Media and global change: Rethinking communication for development (pp. 216-246). Buenos Aires Nordicom.

Fildler, R. et al. (2005). New media theory: Principles of Mediamorphosis. In P. B. Erik, \& B. Shona (Eds.), Living in the information age: A New Media reader. Belmont, USA: Gretchen Otto, G\&S Book Services.

Fred, L. (1990). Postindustrial possibilities: A critique of economic discourse. Berkeley \& Los Angeles, CA: University of California Press.

Garrison, B. (2000). Journalists' perceptions of online information-gathering problems. Journalism and Mass Communication Quarterly, 77(3), 500-514. http://dx.doi.org/10.1177/107769900007700303

Grangvist, M. (2002). Assessing ICT in development: A critical practice perspective In O. Hemer, \& T. Tufte (Eds.), Media and global change: Rethinking communication for development (pp. 285-296). Buenos Aires: Nordicom.

McQuail, D. (1993). Mass communication theory. California: SAGE publications Inc.

Nsereka, B. (2012). Newspaper and magazine production/management (Unpublished monograph, RSUST).

Obijiofor, G. (2003). New technologies and journalism practice in Nigeria and Ghana. Retrieved from http://ro.uow.edu.au/apme/vol.1/iss1414

Ohaja, E.U. (2009). Mass communication research and project report writing. Lagos: John Letterman Ltd.

Okon, G. B. (2001). Basic dimensions in mass communication. Lagos, Nigeria: HdX Communications LTD.

Okunna, C. S. (1999). Introduction to mass communication (2nd ed.). Enugu, Nigeria: New Generation Ventures Limited.

Okwandu, G. A. (2007). Research methods in business and social sciences (2nd ed.). Imo State, Nigeria: Civincs Publishers.

Rodman, G. (2012). Mass media in a changing world: History, industry, Controversy (3rd ed.). New York: McGraw-Hill Companies. 
Samaddar, R. (1995). New technology at the shopfloor level: The story of deunionization in some Indian newspapers. In A. Bagchi (Ed.), New technology and the workers' response: Microelectronics, labour and society (pp. 301-338). New Delhi, India: Sage Publications.

Searvaes, J., \& Malikhao, P. (2005). Participatory communications: The New Paradigms. In O. Hemer, \& T. Tufte (Eds.), Media and global change: Rethinking communication for development (pp. 91-103). Buenos Aires: Nordicom.

Udeze, S. E. (2012). Media law and ethics. Enugu, Nigeria: Rhyce Kerex Publishers Limited.

Uwakwe, O. (2012). Media writing and reporting: who, what, when, where and how (3rd ed.). Enugu, Nigeria: Cecta Books.

Wilson, G. (2005). Local knowledge changing technologies. In T. Skelton, \& T. Allen (Eds.), Culture and Global change (pp. 58-69). New York: Routledge.

Zimbalist, A. (1979). Technology and the labor process in the printing industry. In A. Zimbalist (Ed.), Case studies on the labor process (pp. 103-126). New York, NY: Monthly Review.

\section{Copyrights}

Copyright for this article is retained by the author(s), with first publication rights granted to the journal.

This is an open-access article distributed under the terms and conditions of the Creative Commons Attribution license (http://creativecommons.org/licenses/by/3.0/). 